\title{
A newborn internal and external malformations
}

\author{
Maria Inês Mascarenhas, ${ }_{1}^{1}$ Marta Ferreira, ${ }^{2}$ Jose Miguens, ${ }^{3}$ Rosalina Barroso ${ }^{2}$
}

${ }^{1} \mathrm{HFF}$, Lisbon, Portugal

${ }^{2}$ Department of Paediatrics, Hospital Prof. Doutor Fernando Fonseca EPE, Lisbon, Portugal ${ }^{3}$ Department of Neurosurgery, Hospital Santa Maria-Centro Hospitalar Lisboa Norte, Lisbon, Portugal

\section{Correspondence to} Dr Maria Inês Mascarenhas, ines.mascarenhas@gmail.com

\section{DESCRIPTION}

We presented a case of a female newborn (NB), the fifth daughter of healthy non-consanguineous parents. It was an uneventful biamniotic bicorionic pregnancy except for a prenatal diagnosis of a right clubfoot of the first twin at the 16th week of gestation. A caesarean section was performed at 36-week gestation: the first twin was found to be involved by amniotic adhesions and the skin overlying the right knee was attached to the uterine wall. She also presented an amniotic band constricting the second and third fingers, a malformation of the right lower limb (shortness of the limb and a pterygium between foot dorsum and leg) and a caudal appendage (figures 1 and 2). She was admitted to the neonatal intensive care unit for surveillance.

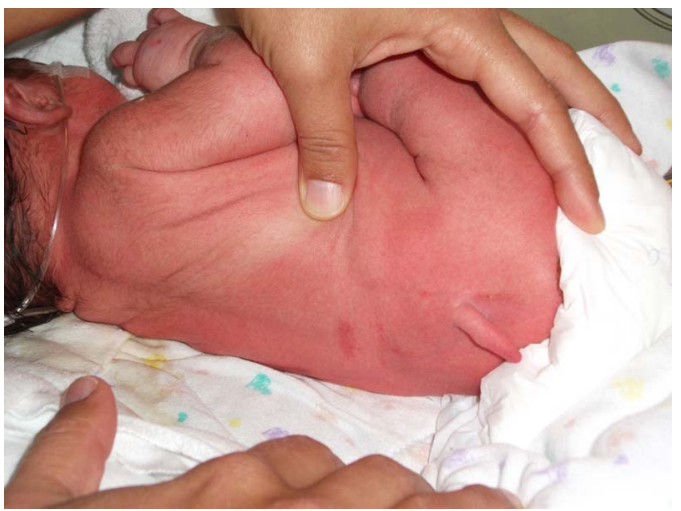

Figure 1 Caudal appendage.

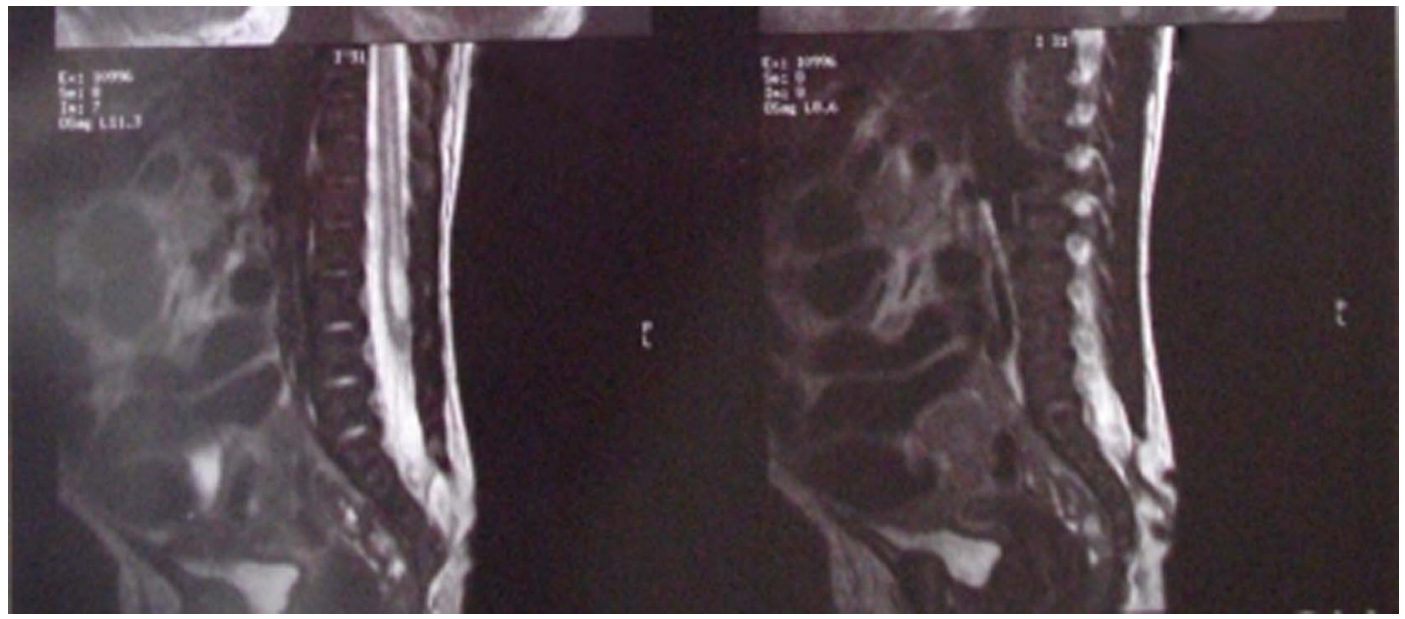

Figure 3 Spinal MRI confirming the presence od spina bifida occulta (S2-S3).
A cranial and spinal MRI was performed and confirmed a spina bifida occulta (figure 3). Further investigation revealed no abdominal, renal or cardiac malformation. Chromosomal analysis was normal. The second twin showed no malformations.

Amniotic band syndrome has an incidence of $1: 1200-1500 \mathrm{NB}$ and can result in various body malformations due to constriction bands with interference in fetal development. ${ }^{1}$ Spinal bifida oculta associated to caudal appendage is due to a failure in the secondary neurulation or segmentation process, which occurs in the first weeks of gestation. $^{2}$

Presently, at 3 years of age she is unable to walk due to the right limb malformation and has

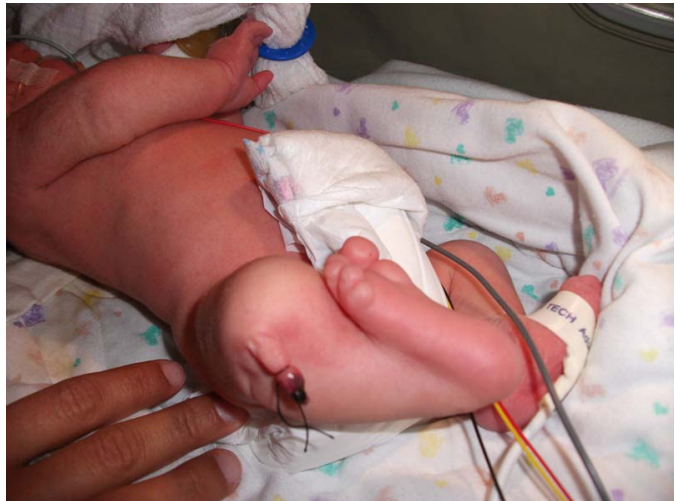

Figure 2 Malformation of the right lower limb (shortness of the limb and a pterygium between foot dorsum and leg) and adhesion of the skin overlying the right knee to the uterine wall (already sectioned).
To cite: Mascarenhas $\mathrm{Ml}$, Ferreira M, Miguens J, et al. BMJ Case Rep Published online: [please include Day Month Year] doi:10.1136/ bcr-2013-009566 
diminished strength in lower limbs as well as no sphincter control (urethral and rectal).

\section{Learning points}

- Association between human tail and limb defects and amniotic bands have been described in the literature. ${ }^{3}$

- Although amniotic bands do not explain the caudal appendage, recurrence of this association suggests a possible common aetiology.

- Experienced prenatal diagnosis could have contributed to counselling and therapeutic orientation.
Contributors MIM and MF were responsible for the newborn while she was admitted in NICU. They were supervised by RB and JM did the follow-up after discharged.

Competing interests None.

Patient consent Obtained.

Provenance and peer review Not commissioned; externally peer reviewed.

\section{REFERENCES}

1 Singh DK, Kumar B, Sinha VD, et al. The human tail: rare lesion with occult spinal dysraphism-a case report. J Pediatr Surg 2008;43:E41-3.

2 Shetty P, Menezes LT, Tauro LF, et al. Amniotic band syndrome. Indian J Surg. Published Online First: Mar 2012. doi:10.1007/s12262-012-0468-x

3 Halbach S, Pei S, Waggoner W. Caudal appendage and limb abnormalities are a recurring pair of birth defects. The University of Chicago Genetic Services. http:/l dnatesting.uchicago.edu/blog

Copyright 2013 BMJ Publishing Group. All rights reserved. For permission to reuse any of this content visit http://group.bmj.com/group/rights-licensing/permissions.

BMJ Case Report Fellows may re-use this article for personal use and teaching without any further permission.

Become a Fellow of BMJ Case Reports today and you can:

- Submit as many cases as you like

- Enjoy fast sympathetic peer review and rapid publication of accepted articles

- Access all the published articles

- Re-use any of the published material for personal use and teaching without further permission

For information on Institutional Fellowships contact consortiasales@bmjgroup.com

Visit casereports.bmj.com for more articles like this and to become a Fellow 